Article

\title{
Training New Professionals in Service Engineering: Towards a Transdisciplinary Curriculum for Sustainable Businesses
}

\author{
Esperanza Marcos, Valeria De Castro $\mathbb{D}$, María-Luz Martín-Peña *(D) \\ and Juan Manuel Vara ${ }^{D}$ \\ Kybele ISe Research Group, Social Science Faculty, Rey Juan Carlos University, \\ 28032 Madrid, Spain; esperanza.marcos@urjc.es (E.M.); valeria.decastro@urjc.es (V.D.C.); \\ juanmanuel.vara@urjc.es (J.M.V.) \\ * Correspondence: luz.martin@urjc.es
}

Received: 15 July 2020; Accepted: 3 October 2020; Published: 8 October 2020

check for updates

\begin{abstract}
The service sector provides employment for more than $70 \%$ of the active population in developed countries, in areas as varied as tourism, commerce, logistics, finances, services, and personnel, amongst others. Despite the fact that society increasingly needs more professionals who are oriented towards this sector, there are hardly any specific plans that will provide them with appropriate training. The appearance of service science, management, and engineering (SSME) has led to a significant advance as regards understanding the skills required by a service professional. It is a transdisciplinary field that integrates aspects of business management, along with information and communication technologies and engineering, and social sciences, in addition to providing the foundations for the growth of sustainable business. This paper presents a curriculum for the training of professionals in service engineering, which has been designed and taught at a Spanish public university. This curriculum, which the university created in collaboration with SSME experts and service sector companies, stands out for two reasons: the transdisciplinary approach employed, which is one of the features of this emerging and integrative knowledge discipline, and the fact that it is providing a response to the need for higher education curricula for sustainable business development. The paper describes the method followed to create the curriculum for the Bachelor's Degree in Service Engineering, a comparative study with other related degrees, and the results of the deployment of the degree in terms of employability.
\end{abstract}

Keywords: service sector; service science management and engineering; service engineering; transdisciplinarity; curricula; sustainable businesses

\section{Introduction}

The service sector does not produce material goods, but rather covers a wide range of activities, such as commerce, transport, communications, finance services, education, health, and tourism, among others. The inclusion of services in the manufacturing sector has given rise to a phenomenon known as servitization, which has broadened the dimension of this sector to an even greater extent [1]. In terms of the world economy, the service sector is now, therefore, responsible for the employment of approximately $65 \%$ of the active population. These data vary, with values of over $78 \%$ in countries such as the United Kingdom, Sweden, Denmark, Canada, and the United States, but suffice it to say that between $60 \%$ and $80 \%$ of the populations in the majority of developed countries are employed in the service sector (source: World Bank data: http://www.worldbank.org/).

Several important professionalization initiatives for the service sector have appeared in recent years. These include research organizations and institutions, such as the SRII (Service Research and 
Innovation Institute, http://www.thesrii.org/) in the US, promoted by a set of leading companies from the sector, the ERISS (European Research Institute in Service Science, http://www.tilburguniversity. edu/research/institutes-and-research-groups/eriss/) whose headquarters are at the University of Tilburg's Business School, or the ISSIP (International Society of Service Innovation Professionals, $h t t p: / / w w w . i s s i p . o r g /)$. The objective of all of the above is to improve the professionalism and quality of the service sector.

This is because a service society requires professionals with specific training that will allow them to tackle the challenges that have come about as a result of this transformation, one of which is sustainable development. The complexity and importance of the service sector signifies that it requires personnel who are qualified in service systems, i.e., dynamic configurations of people, technologies, organizations, and shared information that create and deliver value to customers, providers, and other stakeholders [2]. In other words, there is a need for professionals who understand and can take charge of the complete service system lifecycle, from the conception of new services, to their innovation, design, production, marketing, commercialization, etc., whilst paying attention to the sustainability of these systems and their integration into sustainable businesses. A service professional, therefore, requires a foundation in knowledge attained from different areas, such as economy, marketing, business management, ICT, social responsibility, etc.

A new discipline denominated as Services Science, Management, and Engineering (SSME) made a forceful appearance several years ago. The objective of SSME is to integrate aspects of business management, engineering and technology, and social sciences with the objective of helping organizations defined by service systems to improve their productivity, innovation, and sustainability through the use of skills not possessed by the people who work in each of these separate disciplines $[3,4]$. In a society in which employment is principally generated by the service sector, it is necessary to train professionals in this new discipline, which tackles the development of service systems in sustainable businesses [5]. SSME is a new and different field. Its mission is to discover the underlying logic of complex service systems and to establish common languages and shared frameworks for service innovation [3]. Several authors have stated that an interdisciplinary approach should be adopted for the research and education regarding services systems, and that this should be supported by both businesses and governments.

The sphere of education has now begun to take steps in the direction of providing training in SSME [6,7]. This has, therefore, led to the creation of white papers regarding service science [8,9], which are intended to be the first step as regards creating study plans for the training of professionals in this field. However, any university students who wish to attain an education in this domain must currently design their own curricula, which will involve studying subjects from different bachelor's degrees, master's degrees, or specialized courses. Universities must, therefore, begin to provide a solution to this challenge [2].

One of the pioneers of service science, Jim Spohrer, gave 10 reasons why universities are of importance in the sphere of SSME [2], one of which was the fact that universities have important knowledge related to innovation in services, although it is contained in 'silos,' or isolated disciplines, such as economy, marketing, operations, systems engineering, etc. He, therefore, stated that SSME could assist universities to move from teaching in silos to transdisciplinary teaching, thus adapting to the real needs of a service economy. Various authors consequently discuss the need to train people to become 'T-shaped' professionals, who are highly competent problem solvers in their home discipline but are also capable of interacting with and understanding specialists from a wide range of disciplines and functional areas [3,5]. These professionals are key aspects in the development of sustainable businesses.

It is for all of the aforementioned reasons that educational proposals related to the sphere of SSME have begun to appear in the last few years. Although the majority of university SSME education programs are in the form of master's degrees, some universities have also created bachelor's degrees (see Table A1 in Appendix A). Various authors discuss interdisciplinary or multidisciplinary knowledge, 
but that which can be best adjusted to the needs of a degree of this nature is transdisciplinary knowledge, since it is a new type of knowledge that appears as the result of integrating other already existing types of knowledge and goes further than the knowledge in the disciplines from which it has been obtained. The idea of transdisciplinarity is explained in Section 2 of this work, along with its impact on sustainability. Training a professional in SSME does not, therefore, imply an 'additive' education in knowledge obtained from different disciplines. SSME is a new discipline with its own body of knowledge and study objective: Services and service systems.

In this paper, we propose a curriculum for the training of professionals in SSME at bachelor's degree level, the Bachelor's Degree in Service Engineering, using a holistic and transdisciplinary approach. Although, as stated previously, there are other proposals for bachelor's degrees in this discipline, almost all of them cover only parts of what would be SSME, and very few degrees employ a holistic and transdisciplinary approach. This is the only bachelor's degree of this nature in Spain.

The proposed curriculum is the result of a design and deployment project carried out by a public university (Rey Juan Carlos University) in close collaboration with three significant service companies, each from a different sector: IBM (IT services), EULEN (facility services), and MELIA Hotels International (tourism services). The project has been reviewed and backed by various organizations, such as the ERISS, the SRII, the ISSIP, and the IBM Service Research Centre in Almaden. It is currently being taught in both classroom-based and on-line forms. This year is the third in which students will graduate in the classroom-based format and the first as regards the on-line format. The experience is proving to be highly satisfactory, since it leads to a high level of employability and very positive evaluations of its degree-holders by companies.

The present work is structured as follows: Section 2 presents the body of knowledge required for service science, management, and engineering, and Section 3 provides a summary of the proposed curriculum. Section 4 summarizes the work method followed in order to define the curriculum and presents a comparative study of the proposed training plan and other related degrees, while Section 5 presents the results of the deployment of the degree in terms of employability. Finally, Section 6 presents our principal conclusions and open lines of work for the consolidation of SSME training programs.

\section{Defining a Body of Knowledge for Service Science, Management, and Engineering (SSME)}

The first step required in order to create a new curriculum for the training of professionals in SSME is the definition of the body of knowledge for this new discipline. This concerns identifying both the knowledge that this discipline should contain, i.e., the "what", and the most appropriate model with which to teach that knowledge- the "how". In these times in which services have taken on the pivotal place in the economy, it is essential to develop, evaluate, and revise a theoretical framework that will support service science research and development, along with its related disciplines [10].

\subsection{What Knowledge Areas Does SSME Include?}

There are various proposals regarding the body of knowledge that SSME teaching should cover. In 2004, in the document "Service Science: A New Academic Discipline?" IBM stated that service science could bring together ongoing work in the more established fields of computer science, operations research, industrial engineering, mathematics, management sciences, decision sciences, social sciences, and legal sciences to create new skills and markets that offer services that will help transform, optimize, and manage business-support functions in organizations [9]. The Cambridge Service Science, Management, and Engineering Symposium of 2007 [3] similarly stressed the importance of uniting the knowledge originating from computer science, operations research, industrial engineering, business strategy, management sciences, and social and legal sciences, with the objective of training professionals who will help improve organizations' success through the innovation of services. It is also necessary to consider orientation towards sustainable businesses. One of the differentiating aspects as regards training in services is the integration of these types of knowledge into one single body of knowledge, as will be seen in the "how". 
Although there are several proposals concerning what the aforementioned body of knowledge should be in SSME $[6,8,11]$, they all coincide as regards indicating three key types of skills that a service engineer should have: Business and management skills, information systems engineering skills (or technological skills), and socio-organizational skills. The knowledge related to these skills provided at universities is generally taught on different bachelor's and master's degrees that can be grouped in three large areas (Figure 1): Business and processes, engineering and technology, and people and culture [6].

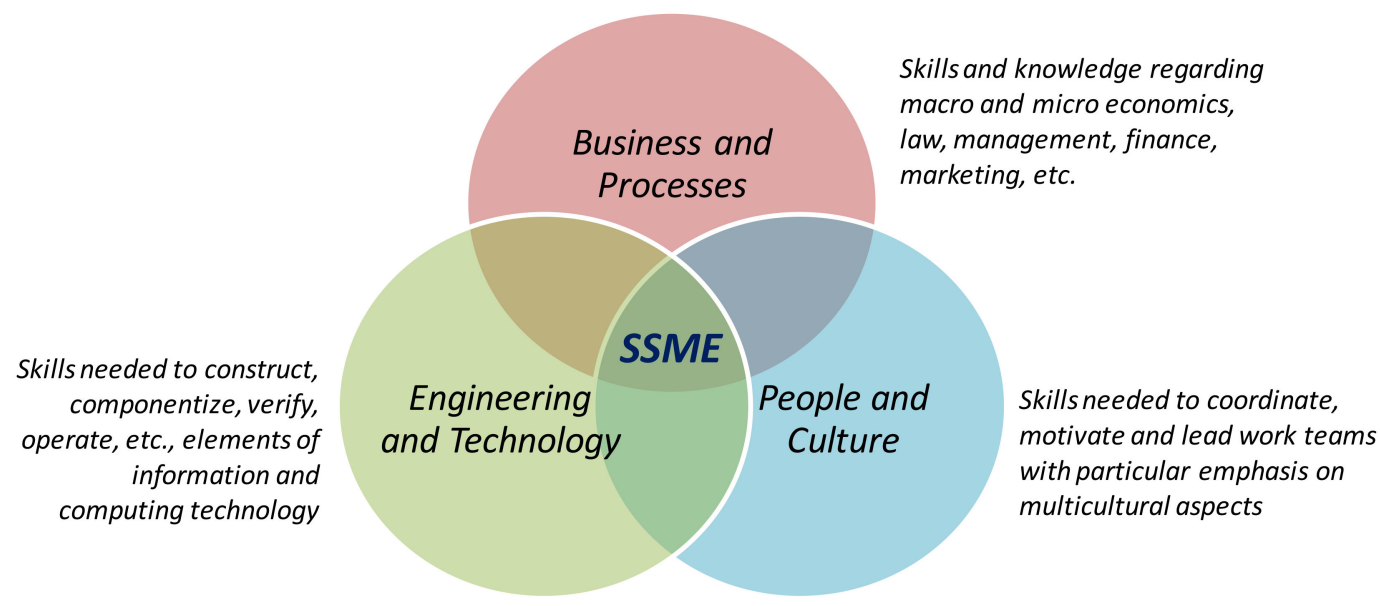

Figure 1. Relationship between service science, management, and engineering (SSME) professionals' knowledge and skill areas.

In SSME, the study object is the service, independently of the sector, and whether or not this is supported by technology. Its objective is, meanwhile, to study the laws that regulate the behavior of the complex service systems and to establish a common language and body of knowledge for service innovation [12].

SSME seeks to integrate teaching in these areas by designing a curriculum that will permit the training of professionals who are highly capable of working in different fields related to services and sustainable businesses. In order to satisfy these needs, SSME defends the concept of a new type of professional for the service sector: The service engineer. This professional is trained by combining the areas of knowledge of SSME with a T-shaped profile [13].

Service engineers must have in-depth knowledge (the vertical part of the $\mathrm{T}$ ) of at least one discipline (business, information technology, etc.), and of at least one domain (health, IT, tourism, etc.). They must also complete their professional profiles with transversal knowledge (the horizontal part of the T), such as: a capacity to understand and communicate with professionals with different profiles, the capacity to work in a team, leadership, project management, critical thought, systematic thought, languages, adaptation and flexibility, multiculturalism, globalization, etc. [4].

\subsection{How Can the SSME Knowledge Areas Be Integrated into a Service Engineering Curriculum?}

The challenge of providing training in SSME lies in not only linking together the basic types of knowledge required for the discipline in a curriculum, but also (and perhaps more importantly) the approach employed to integrate them. This integration can be tackled in different ways [3] according to what the knowledge in the new discipline is considered to be:

- Multidisciplinary: This implies the union of knowledge or skills from different disciplines. This multidisciplinary knowledge can be obtained by either uniting all the knowledge from the disciplines of which it is formed (superset) or uniting parts of the knowledge from the original disciplines (subset) (Figure 2a). 
- Interdisciplinary: Interdisciplinarity implies the integration of knowledge that has originated from different disciplines (Figure $2 b$ ).

- Transdisciplinary: Transdisciplinarity also integrates the knowledge from other disciplines, but goes one step further since, as its name indicates, it transcends these disciplines in order to create new knowledge (Figure 2c).

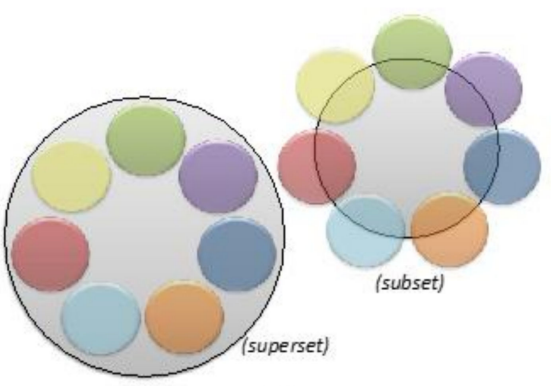

(a)

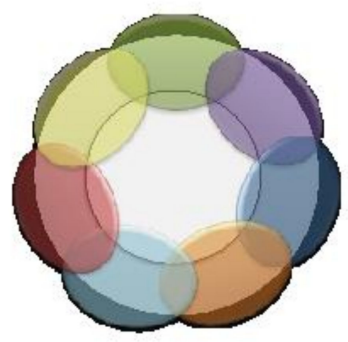

(b)

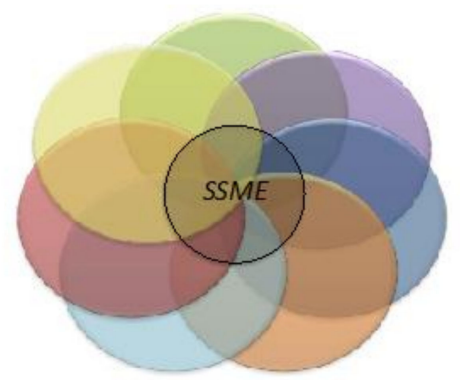

(c)

Figure 2. Approaches for the integration of disciplines. (a) Multidisciplinary, (b) interdisciplinary, (c) transdisciplinary.

When applied to education, a transdisciplinary approach implies obtaining holistic learning and tasks that transcend and go further than the traditional disciplines of knowing and knowledge. This approach is optimum for the training of professionals in service engineering, since there is a body of knowledge and its study object (the service and service systems), which can be applied to all the disciplines and which transcend the knowledge and fields of study of each of them [3].

The argument above led us to consider the best way in which to integrate the concepts from the different disciplines in order to attain a body of knowledge specific to SSME. Two possible models for bachelor's degrees are proposed in [14]:

- $\quad$ Topical sequence (Figure 3a): The model traditionally employed to carry out multiple teaching is the topical sequence model. A topic is taught to whatever depth of understanding is required before moving on to the next one.

- Spiral sequence (Figure 3b): During which the learner explores the same topics in different phases, starting with the basics of each topic and then learning about them in increasingly greater depth.

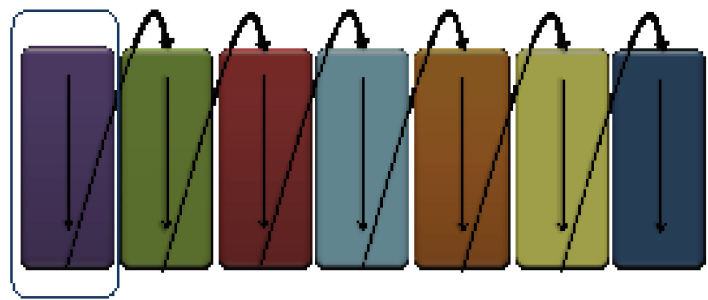

(a)

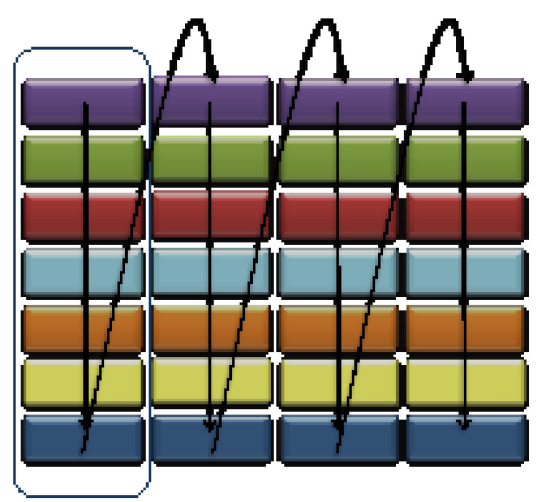

(b)

Figure 3. Means of integrating concepts from different disciplines. (a) Topical sequence, (b) spiral sequence. 
The topical approach is appropriate for teaching of a multidisciplinary nature, in which the most important aspect is to transmit the knowledge related to the disciplines implied, but the order in which that knowledge is taught is not important.

The spiral approach considers that the materials from the different disciplines should be taught in a logical sequence, since the knowledge from certain disciplines is integrated with that from others. Although [14] states that this approach is suitable for the teaching of SSME, we consider that this type of design is more suitable for interdisciplinary rather than transdisciplinary teaching.

On a service engineering degree, there should be a logical sequence among the materials from the various disciplines of which it is composed. But its transdisciplinary nature signifies that not only is the sequence of the materials important, but also their content, and this content also requires a different approach to that employed in the specific discipline from which it originated and should be specific to the new discipline, in this case SSME. As is stated in [15] "transdisciplinary work moves beyond the bridging of divides within academia to engaging directly with the production and use of knowledge outside of the academy." We, therefore, propose a new approach for the teaching of material on a service engineering degree in an attempt to reflect the idea of the holistic teaching of services. This integration approach is shown in Figure 4, in which there is a three dimensional spiral sequence, and in which the idea of service (represented in the circle in the center of the figure) is the common thread of the teaching. Note that the materials from the various disciplines are represented using different colored circles. Each color represents a discipline, while the central circle indicates that all of these study objects are services, be they from a technological, humanistic, or business dimension. This approach is also appropriate as regards incorporating the concepts of sustainability into higher education curriculums $[16,17]$.

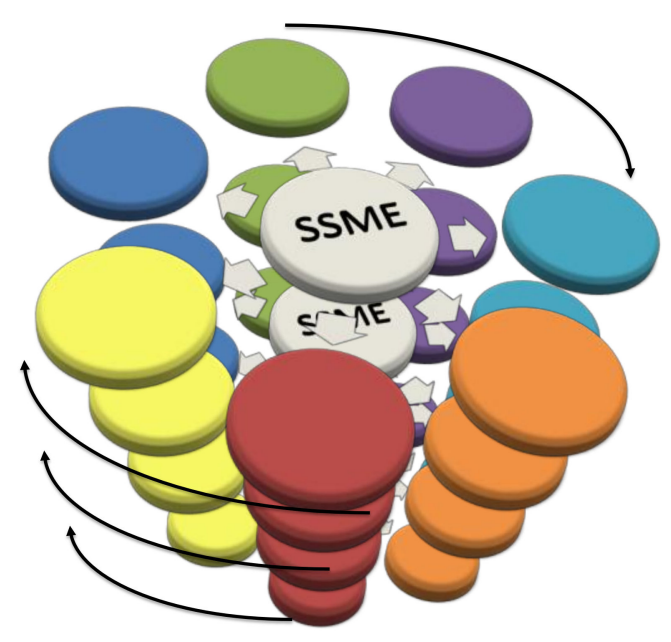

Figure 4. Holistic sequence: Integration for a transdisciplinary curriculum in service engineering.

Despite the importance of and the need to create appropriate professional profiles for the service sector by bringing together the knowledge and skills from different areas in a transdisciplinary profile in order to train professionals that are capable of working in different fields related to services, of creating sustainable businesses and of managing information technologies for a more human/social perspective, there is currently a significant "gap" between the training needs demanded by service companies and the training plans currently offered by universities.

In the following section, we present the Bachelor's Degree in Service Engineering developed at the Rey Juan Carlos University in which this transdisciplinary approach and holistic teaching are used with the intention of covering this gap. We shall analyze the materials included in the degree, along with the way in which those materials are taught throughout the course. A comparison of the different academic programs that currently exist at an international level is provided in Section 4 


\section{A Service Engineering Curriculum. Inductive-Deductive Approach}

Since the first work related to SSME appeared, various universities worldwide have begun to create study plans in order to cover education in this area [6]. The majority of the initiatives that currently exist are master's degree Programs.

We present the Service Engineering Curriculum developed at the Rey Juan Carlos University (RJCU). When designing a curriculum in service engineering by means of the approaches established in the previous section, we followed a multidimensional inductive-deductive approach. In the deductive dimension we, therefore, carried out a literature review and we collected the opinions of experts in this matter (defining what to include), while in the inductive dimension we explored the reality of professors working in this area and the way in which they perceive the relevance, usefulness, and the evidence itself as regards the concepts of service engineering when teaching it (defining thus how to teach).

\section{1. "What" to Include}

The proposals of various experts in SSME [3,6,14], along with an analysis of the different curricula taught at an international level [18-20], were employed as a means to identify the principal materials that should be taught. These materials have been grouped in blocks, denominated as modules, in order to establish groups of materials whose themes are related to each other. The relationships among these modules and the three large areas of which SSME is composed, as proposed in the previous section, are shown in Figure 5. The modules defined are:

- Foundations: This involves attaining a base in the knowledge of mathematics and statistics, along with other basic concepts required by a service professional, such as the theory of systems, the history of services, and the basic ethical and legal aspects of any profession. This knowledge is principally related to the areas of engineering and technology and business and processes.

- Business and management: This involves knowledge related to business management, sustainable businesses, human resources and marketing. This block of materials is encompassed in the area of business and processes.

- Social science: This involves knowledge from economics and sociology degrees. This knowledge is related to the areas of business and processes and people and culture.

- Information systems: This involves knowledge of information systems and databases. These materials are related to the areas of engineering and technology and business and processes.

- Information technology and communications (ITC): This involves knowledge related to technical and computer engineering skills, such as architectures, hardware, programming, networks, operating systems, etc. These materials are from the area of engineering and technology.

- Service management: This involves knowledge related to service management in organizations, such as service engineering, service management, quality of services, service process management, etc. This type of knowledge, which is fundamental from the point of view of services, is related to the three large areas of SSME.

- Psychology and communications: This involves knowledge regarding psychology and communication and is related to social skills, such as communication skills, emotional intelligence, the management of work teams, leadership, etc. These materials are encompassed within the area of people and culture.

Each of these modules is made up of materials, and each material may have one or more subjects, as shown in Tables 1-3. Each of these subjects allows the student to acquire a set of competences and skills. 


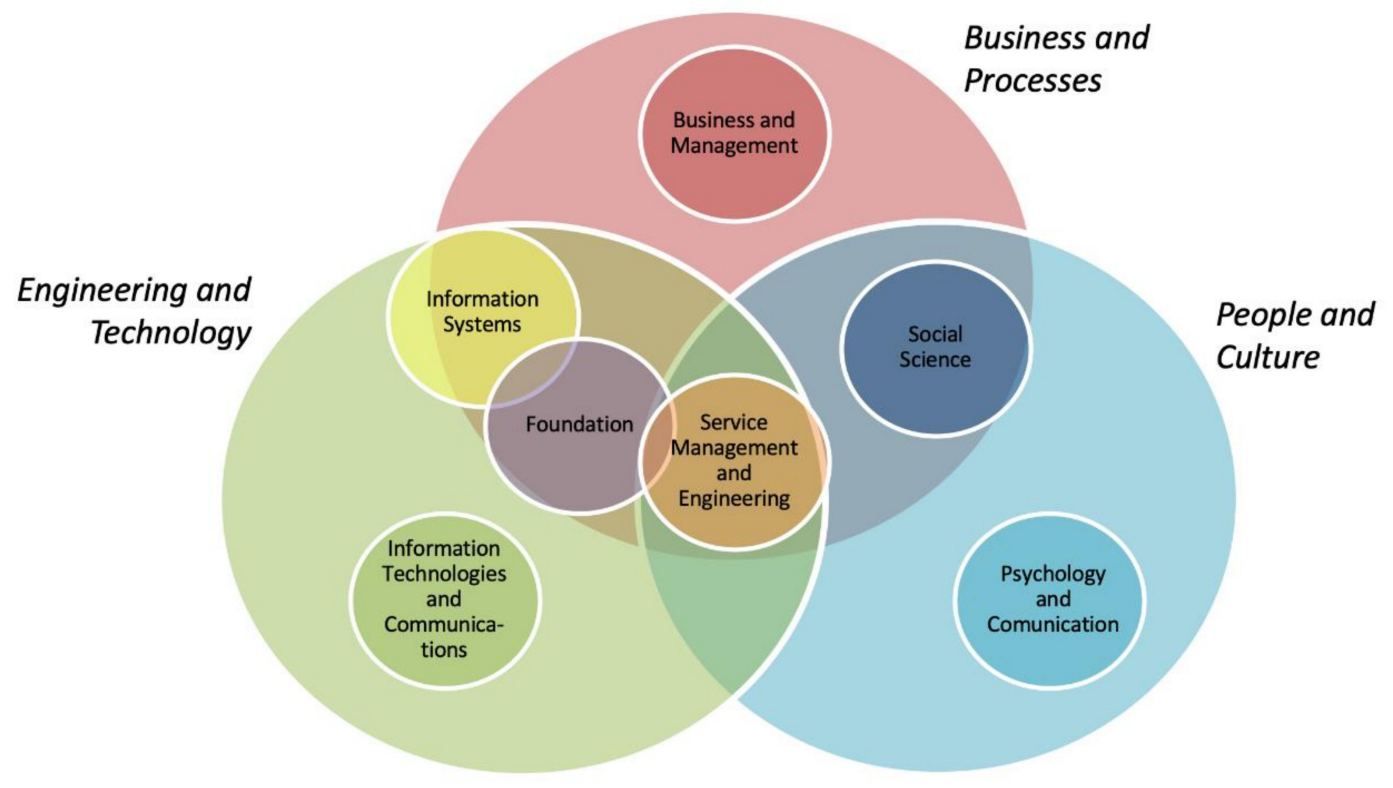

Figure 5. Relationships among modules according to areas in SSME.

Table 1 includes the subjects and topics related to "Foundation" and "Business Management" modules. The Foundation module has been organized in six materials that include the basic knowledge required by a service professional, such as mathematics and logic, statistics and operation research, history of services and systems theory, in addition to basic subjects required by Rey Juan Carlos University, such as modern languages and ethical and legal issues. The Business and Management module has been organized in just one material that includes seven subjects according to the module's training needs and whose topics have been adapted to the management and business of the service sector.

Table 2 includes the subjects and topics related to "Social Science" and "Psychology and Communications" modules. The Social Science module is structured around two materials, economics and sociology, and includes four subjects whose topics have also been adapted to the service sector, such as service science economics or service sociology. The Psychology and Communications module is structured in two materials and three subjects focused on the development of social and communication skills.

Subjects and topics related the modules of "Information and Communication Technologies," "Information Systems," and "Service Management and Engineering" are described in Table 3. The Information and Communication Technologies and Information Systems modules are both organized around one material that includes different subjects that cover the specific training needs of each module, and with topics focused on the study of service technologies and service systems. The Service Management and Engineering module is organized around four subjects that cover the knowledge of service management and engineering, along with elective subjects (four, in accordance with the regulations of Rey Juan Carlos University) that include specific knowledge of applications in different areas of the service sector, such as public administration, banking and insurance, tourism, health, etc.). 
Table 1. Rey Juan Carlos University (RJCU) SSME Service Engineering Curriculum. "Foundation" and “Business Management" modules.

\begin{tabular}{|c|c|c|}
\hline Module & Subject & Topics \\
\hline \multicolumn{3}{|r|}{ Foundation } \\
\hline Modern Languages & Modern Languages & $\begin{array}{c}\text { Grammar. Oral expression. Written expression. } \\
\text { Characteristics of language in commercial and business } \\
\text { spheres. }\end{array}$ \\
\hline \multirow{2}{*}{$\begin{array}{l}\text { Mathematics and } \\
\text { Logic }\end{array}$} & $\begin{array}{c}\text { Mathematics for } \\
\text { Computation and Services }\end{array}$ & $\begin{array}{l}\text { Discrete Mathematics. Linear algebra. Boolean algebra. } \\
\text { Relationships. Graphs. Calculus. }\end{array}$ \\
\hline & Logic & $\begin{array}{l}\text { Introduction to logic. Logic of propositions. First order } \\
\text { predicate logic. }\end{array}$ \\
\hline \multirow{2}{*}{$\begin{array}{l}\text { Statistics and } \\
\text { Operation Research }\end{array}$} & Statistics & $\begin{array}{l}\text { Descriptive statistics. Probabilities and random variables. } \\
\text { Simulation. Statistical models. Position measures. Sampling } \\
\text { and population. }\end{array}$ \\
\hline & Operation Research & $\begin{array}{c}\text { Introduction to operation research. Methodology and model } \\
\text { formation. Linear and non-linear programming. } \\
\text { Multi-objective linear programming. }\end{array}$ \\
\hline History & $\begin{array}{l}\text { History and Fundamentals } \\
\text { of Services }\end{array}$ & $\begin{array}{l}\text { History of services. Concept of services. Characteristics of } \\
\text { services. Types of services. Service views (business services, } \\
\text { electronic services, technological services, etc.). Service Model. } \\
\text { Service Science. }\end{array}$ \\
\hline Systems Theory & Systems Theory & $\begin{array}{c}\text { Systematic thinking. Biological systems. Basic concepts of } \\
\text { systems. Characteristics and properties. General Systems } \\
\text { Theory. Constructive elements. Types of cycles. Generic } \\
\text { structures: archetypes. }\end{array}$ \\
\hline \multirow[t]{2}{*}{ Legal issues } & $\begin{array}{l}\text { Ethical, Legal, and } \\
\text { Professional Aspects }\end{array}$ & $\begin{array}{l}\text { Ethics. Social corporative responsibility. Competencies of } \\
\text { Service Engineers. Profiles. Roles. Professional Outlets. } \\
\text { Ethical aspects of Service Sciences and Management. } \\
\text { Computing Legislation. National and European legislation. }\end{array}$ \\
\hline & Private Law & Sourced from Civil Law. Sourced from Mercantile Law. \\
\hline \multicolumn{3}{|c|}{ Business and Management } \\
\hline \multirow{7}{*}{$\begin{array}{l}\text { Business and } \\
\text { Management }\end{array}$} & Business Organization & $\begin{array}{l}\text { The business and its objectives. The company's relationship } \\
\text { with its environments. Managers at the Company. Decision } \\
\text { Making. Functions of Management. The organization's } \\
\text { functional areas. Sustainable Business. }\end{array}$ \\
\hline & $\begin{array}{l}\text { Service Operation } \\
\text { Management }\end{array}$ & $\begin{array}{l}\text { Service companies vs. Industrial companies. Service vs. } \\
\text { Process. The function of Operations. Processes. Localization. } \\
\text { Capacity. Plant Layout. Service Quality. Environmental } \\
\text { Protection. }\end{array}$ \\
\hline & $\begin{array}{l}\text { Strategic Management of } \\
\text { Businesses and } \\
\text { Service-Oriented Business } \\
\text { Consultancy }\end{array}$ & $\begin{array}{l}\text { The Nature of Strategic Management. Strategic Management } \\
\text { Processes. Vision, Mission, Values. Strategic Analysis. Internal } \\
\text { Analysis. Use of Strategies. Sustainable Business Models. The } \\
\text { Service Professionals' Company. The Company's Evolutive } \\
\text { Process. }\end{array}$ \\
\hline & Business Initiative & $\begin{array}{l}\text { The Entrepreneurial Spirit. The creation of a sustainable } \\
\text { enterprise. The creation of a business plan. Production plans. } \\
\text { Financial-economic plans. Marketing plans. }\end{array}$ \\
\hline & Human Resources & $\begin{array}{c}\text { Human Resources at the company. Workflow management } \\
\text { and job analysis. Human Resource planning. Staffing and } \\
\text { Development Processes. Evaluation and compensation } \\
\text { processes. }\end{array}$ \\
\hline & Service Marketing & $\begin{array}{l}\text { Concept of marketing. Marketing's role within the company. } \\
\text { Market research, product and pricing policies, commercial } \\
\text { distribution, sales management. The fundamentals of the } \\
\text { Marketing mix in services. Environment and Market. } \\
\text { Fundamentals of international commerce. }\end{array}$ \\
\hline & Business Communication & $\begin{array}{c}\text { Principles and concepts of communication. Communication } \\
\text { plans. Internal communication. External communication } \\
\text { Dossier programming. }\end{array}$ \\
\hline
\end{tabular}


Table 2. RJCU SSME Service Engineering Curriculum. "Social Science" and "Psychology and Communications" modules.

\begin{tabular}{|c|c|c|}
\hline Module & Subject & Topics \\
\hline & & Social Science \\
\hline \multirow{3}{*}{ Economics } & $\begin{array}{l}\text { Service Science } \\
\text { Economics }\end{array}$ & $\begin{array}{l}\text { Principles of macroeconomics. Market analysis and structure. Economic } \\
\text { models. Principles of accountancy and national taxation. }\end{array}$ \\
\hline & $\begin{array}{l}\text { Financial Economics } \\
\text { and Accounting }\end{array}$ & $\begin{array}{l}\text { Introduction to financial markets. Introduction to financial mathematics. } \\
\text { Investment values. Profitability and share and portfolio risks. Investment } \\
\text { management. Share value models. Markets and portfolios. Fixed income } \\
\text { markets. Sustainable finance. }\end{array}$ \\
\hline & Microeconomics & $\begin{array}{l}\text { The principles of microeconomics. The analysis and structure of economic } \\
\text { agents. Economic models. }\end{array}$ \\
\hline Sociology & Service Sociology & $\begin{array}{l}\text { Social aspects of services. The social role of service providers and } \\
\text { consumers. Social relationships applied to services. Collaborative services. }\end{array}$ \\
\hline \multicolumn{3}{|r|}{ Psychology and Communications } \\
\hline \multirow{2}{*}{ Psychology } & $\begin{array}{l}\text { Emotional } \\
\text { Intelligence }\end{array}$ & $\begin{array}{l}\text { Rational intelligence and emotional intelligence. Emotional self-control. } \\
\text { Basic emotional intelligence capabilities. Emotional intelligence in the } \\
\text { workplace. Emotions and moods. Negotiation. }\end{array}$ \\
\hline & $\begin{array}{l}\text { Leadership and } \\
\text { Group Work }\end{array}$ & $\begin{array}{l}\text { Theories and types of leadership. Leadership skills. Vision, mission, and } \\
\text { beliefs. Teamwork. Group work. The importance of group work in a } \\
\text { company. Systematic vision of teams. Time management. }\end{array}$ \\
\hline Communication & $\begin{array}{l}\text { Communication } \\
\text { Skills }\end{array}$ & $\begin{array}{l}\text { Types of Communication: verbal and non-verbal communication. } \\
\text { Communication strategies and techniques. Analysis of the barriers that } \\
\text { have a negative effect on communication efficiency. }\end{array}$ \\
\hline
\end{tabular}

\section{2. "How" to Teach}

Table 4 shows the distribution of the subjects, corresponding to each of the SSME modules, throughout the four years of the degree. As will be noted in Tables 1-3 (contents of subjects) and Table 4 (sequence of subjects), the model of the curriculum corresponds to the holistic model, which is proposed as being the most recommendable for transdisciplinary teaching, as is the case of SSME. Table 4 shows that each of these areas is developed gradually, in increasingly greater depth, while Tables 1-3 show that the contents of the subjects are focused on services.

Figure 6 shows how the teaching of each subject is distributed throughout the four years, along with the credits for the subjects taught in each of the modules. As will be noted in the graphics, both the first and second years have a high percentage of subjects corresponding to foundations. The service management and engineering subjects are taught fundamentally in the third year. The fourth year includes credits for placements at businesses (work experience) and the dissertation, and those credits that are not classified for a specific module.

Many of the degrees offered at an international level have been conceived as specializations: Either specializations in service-based information technologies for business studies graduates, or specializations in services management for computing studies graduates. SSME is not, however, a specialization in business or computing studies. It is a scientific discipline that has arisen as a result of the confluence of various disciplines.

The students at RJCU receive an integrated multi-disciplinary education with a combined perspective from the very beginning. The acquisition of the interdisciplinary skills related to services takes place gradually throughout the degree and allows them to progress steadily in all the disciplines until they attain the level of maturity required for their target sphere of employment. The use of innovative and modern educational methodologies, classes very focused on problem solving and the use of more attractive techniques for students [21], are undoubtedly other strengths of this training. 
Table 3. RJCU SSME Service Engineering Curriculum. "Information and Communication Technologies," "Information Systems," and "Service Management and Engineering" modules.

\begin{tabular}{|c|c|c|}
\hline Module & Subject & Topics \\
\hline & & Information and Communication Technologies \\
\hline \multirow{8}{*}{$\begin{array}{l}\text { Information } \\
\text { and } \\
\text { Communication } \\
\text { Technologies }\end{array}$} & $\begin{array}{l}\text { Operating Systems } \\
\text { and Networks }\end{array}$ & $\begin{array}{l}\text { Fundamentals. Communication network, intra-computing and between computer } \\
\text { models. Communication protocols and standards. Wireless communication networks. } \\
\text { OS and Network Security. }\end{array}$ \\
\hline & $\begin{array}{l}\text { Introduction to } \\
\text { Programming }\end{array}$ & $\begin{array}{l}\text { Fundamentals. The principles of computing. Programming elements. Object oriented } \\
\text { programming. Concepts of encapsulation, visibility, overloading, inheritance and } \\
\text { polymorphism, exceptions, interfaces. }\end{array}$ \\
\hline & $\begin{array}{l}\text { Service } \\
\text { Development }\end{array}$ & $\begin{array}{l}\text { Communication protocols among services. XML technologies. Service technologies. } \\
\text { Service languages and standards. Discovery of services. Service-based programming } \\
\text { and associated tools. }\end{array}$ \\
\hline & $\begin{array}{l}\text { Mobile and } \\
\text { Ubiquitous Services }\end{array}$ & $\begin{array}{l}\text { Fundamentals of mobile and ubiquitous computing. Mobile service development and } \\
\text { execution platforms. Ubiquitous computing-based applications and systems } \\
\text { development. Context-aware programming and service adaptation. Sensor networks. }\end{array}$ \\
\hline & $\begin{array}{l}\text { Service Design } \\
\text { and Maintenance }\end{array}$ & $\begin{array}{c}\text { Architectonic styles. Service-oriented architectonic patterns. Service design and } \\
\text { integration design patterns. Deployment, testing and monitoring of service-oriented } \\
\text { systems. Service security. }\end{array}$ \\
\hline & $\begin{array}{l}\text { Human-Computer } \\
\text { Interaction and } \\
\text { Multimedia }\end{array}$ & $\begin{array}{l}\text { Human factors. Adaptation to sensorial and intellectual disabilities. Friendly interface } \\
\text { design methods. Help systems design. Principles of graphic design. Multimedia } \\
\text { application programming. }\end{array}$ \\
\hline & $\begin{array}{l}\text { Computer } \\
\text { Architecture }\end{array}$ & $\begin{array}{l}\text { Historical perspective of computers. Central Processing Unit. Memory hierarchies. } \\
\text { Input and output organization. }\end{array}$ \\
\hline & $\begin{array}{l}\text { Software } \\
\text { Engineering }\end{array}$ & $\begin{array}{l}\text { Introduction to Software Engineering. Lifecycles. The concept of processes and } \\
\text { development methodologies. Introduction to systems specification: modelling } \\
\text { languages and automata theory. }\end{array}$ \\
\hline \multirow{8}{*}{$\begin{array}{l}\text { Information } \\
\text { Systems }\end{array}$} & \multicolumn{2}{|r|}{ Information Systems } \\
\hline & $\begin{array}{l}\text { Information } \\
\text { Systems }\end{array}$ & $\begin{array}{l}\text { The concept of information systems. Business information systems. Types of basic } \\
\text { information systems. Evolution of information systems. Integrated information systems. }\end{array}$ \\
\hline & $\begin{array}{l}\text { Business } \\
\text { Architectures }\end{array}$ & $\begin{array}{l}\text { Business architecture lifecycles. The establishment of vision, internal and external state } \\
\text { of a company via its business architecture. Business architecture components. Specific } \\
\text { business architectures. }\end{array}$ \\
\hline & $\begin{array}{l}\text { Business } \\
\text { Information } \\
\text { Systems }\end{array}$ & $\begin{array}{l}\text { Fundamentals of business management systems. ERP. Evolution, architecture,, and } \\
\text { general characteristics of ERP systems. Selection criteria of ERP. CRM, SCM. E-business } \\
\text { systems. }\end{array}$ \\
\hline & $\begin{array}{l}\text { Business } \\
\text { Intelligence and } \\
\text { Analysis }\end{array}$ & $\begin{array}{l}\text { Data mining techniques. Web mining. Decision support systems. Balanced scorecard. } \\
\text { Company business intelligence. Competitive intelligence within the organization. }\end{array}$ \\
\hline & Data Bases & $\begin{array}{l}\text { Files. The concept of DB and DBMS. Architecture and components. Data conceptual } \\
\text { models. The Relational Model. The SQL language. Data-base design. DB security. }\end{array}$ \\
\hline & $\begin{array}{l}\text { Information } \\
\text { Systems } \\
\text { Architecture }\end{array}$ & $\begin{array}{l}\text { The fundamentals of distributed systems. Communication architectures for distributed } \\
\text { systems. Service-based architectures. Business-based architectures. Enterprise } \\
\text { Architecture Integration (EAI). Business-to-Business/to-Consumer (B2B, B2C). }\end{array}$ \\
\hline & $\begin{array}{l}\text { Technologies for } \\
\text { the Management } \\
\text { of Large Volumes } \\
\text { of Data }\end{array}$ & $\begin{array}{c}\text { Introduction to Data Stores: architecture and components. Data store. OLAP tools. Data } \\
\text { store design. Data store maintenance. Extraction, transformation, and load processes. } \\
\text { Non-structured data management }\end{array}$ \\
\hline \multirow{6}{*}{$\begin{array}{l}\text { Service } \\
\text { Management } \\
\text { and } \\
\text { Engineering }\end{array}$} & \multicolumn{2}{|r|}{ Service Management and Engineering } \\
\hline & $\begin{array}{c}\text { Service } \\
\text { Management }\end{array}$ & $\begin{array}{l}\text { Service portfolio. Service levels. Availability, capacity. Supplier management. Design } \\
\text { coordination. Incidents, problems, configuration, change. ITIL. Service quality. }\end{array}$ \\
\hline & Service Engineering & $\begin{array}{l}\text { The fundamentals of Service Engineering. Service lifecycles. Service-oriented } \\
\text { development methods. Requirements Engineering for the discovery of services. Service } \\
\text { analysis and modelling. }\end{array}$ \\
\hline & $\begin{array}{c}\text { Project } \\
\text { Management }\end{array}$ & $\begin{array}{c}\text { Fundamentals of project management. Project planning. CASE Tools. Project estimation. } \\
\text { Risk Management. Agile Project Management. }\end{array}$ \\
\hline & $\begin{array}{l}\text { Business Process } \\
\text { Engineering }\end{array}$ & $\begin{array}{c}\text { Business process management (BPM). Process oriented management systems. Process } \\
\text { modelling languages. Business process re-engineering. The evolution and } \\
\text { modernization of business processes. }\end{array}$ \\
\hline & Optional/Elective & $\begin{array}{c}\text { Service Applications: Public Administration, Education and Science, Residential and } \\
\text { Urban, Banking and Insurance, Industrial, Services in Energy and Utilities, Tourism, } \\
\text { Health, Commercial Distribution, Telecommunications, Information Technology, } \\
\text { Consultation. }\end{array}$ \\
\hline
\end{tabular}


Table 4. Distribution of subjects per term in the RJCU Service Engineering Curriculum.

\begin{tabular}{|c|c|c|c|c|c|}
\hline First Year & Credits & Term & Second Year & Credits & Term \\
\hline $\begin{array}{c}\text { Mathematics for Computation } \\
\text { and Services }\end{array}$ & 6 & 1 & English & 6 & Annual \\
\hline Theory of Systems & 3 & 1 & Statistics & 6 & 1 \\
\hline $\begin{array}{l}\text { History and Fundamentals } \\
\text { of Services }\end{array}$ & 6 & 1 & Private Law & 6 & 1 \\
\hline Service Sociology & 6 & 1 & Communication Skills & 6 & 1 \\
\hline Introduction to Programming & 6 & 1 & Service Design and Maintenance & 3 & 1 \\
\hline Computer Architecture & 3 & 1 & Data Bases & 6 & 1 \\
\hline Logic & 3 & 2 & Operation Research & 3 & 2 \\
\hline $\begin{array}{l}\text { Ethical, Legal, and } \\
\text { Professional Aspects }\end{array}$ & 6 & 2 & Business Communication & 6 & 2 \\
\hline Business Organization & 6 & 2 & Economy in Service Sciences & 6 & 2 \\
\hline Emotional Intelligence & 3 & 2 & Software Engineering & 3 & 2 \\
\hline Service Development & 6 & 2 & Information Systems Architecture & 6 & 2 \\
\hline Operating Systems and Networks & 6 & 2 & Information Systems & 3 & 2 \\
\hline Third Year & Credits & Term & Fourth Year & Credits & Term \\
\hline Service Operation Management & 3 & 1 & Dissertation & 6 & Annual \\
\hline Microeconomics & 3 & 1 & Work Experience & 24 & Annual \\
\hline Leadership and Teamwork & 3 & 1 & Recognition of Credits/SSME Seminary & 6 & 1 \\
\hline Business Information Systems & 6 & 1 & $\begin{array}{l}\text { Strategic Business Management and } \\
\text { Service-Oriented Business Consultation }\end{array}$ & 3 & 1 \\
\hline $\begin{array}{l}\text { Technologies for the Management } \\
\text { of Large Volumes of Data }\end{array}$ & 6 & 1 & Business Architectures & 3 & 1 \\
\hline Service Engineering & 6 & 1 & Elective: Service Applications & 3 & 1 \\
\hline Project Management & 3 & 1 & Elective: Service Applications & 3 & 1 \\
\hline Service Marketing & 6 & 2 & Business Initiative & 3 & 2 \\
\hline $\begin{array}{l}\text { Financial Economy } \\
\text { and Accounting }\end{array}$ & 3 & 2 & Human Resources & 3 & 2 \\
\hline Mobile and Ubiquitous Services & 3 & 2 & Elective: Service Applications & 3 & 2 \\
\hline $\begin{array}{l}\text { Human-Computer Interaction } \\
\text { and Multi-media }\end{array}$ & 6 & 2 & Elective: Service Applications & 3 & 2 \\
\hline Business Intelligence and Analysis & 3 & 2 & & & \\
\hline Business Process Engineering & 3 & 2 & & & \\
\hline Service Management & 6 & 2 & & & \\
\hline
\end{tabular}
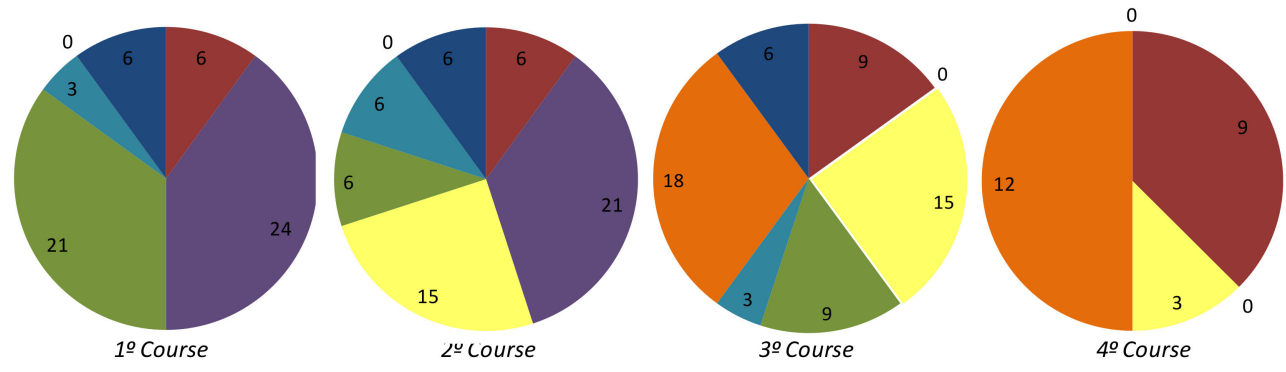

\begin{tabular}{|c|c|}
\hline Foundation & Bussines and Management \\
\hline Social Science & Esychology and communications \\
\hline Information Technologies and Communications & Information Systems \\
\hline Service Management and Engineering & \\
\hline
\end{tabular}

Figure 6. Distribution of credits per module in the RJCU Service Engineering Curriculum. 


\section{Work Method. Analysis and Comparison of the Proposed Degree with Other Degrees}

The proposed degree is formed of a set of subjects from different disciplines that have been integrated by following a transdisciplinary model and holistic teaching. These disciplines, which unite what is considered to be the key knowledge required by SSME professionals, are also present in the majority of bachelor's and master's degrees taught at an international level (Appendix A, Table A1).

Figure 7 provides a summary of the work method followed to create the proposed curriculum. Once the need for a new type of professional for the service sector was detected, and before beginning to define the curriculum, one important part of the work was the data collection. This involved collaborating with service companies in order to discover their training needs and analyzing similar bachelor's and master's in the area. Such analysis and comparison are presented below in this section.

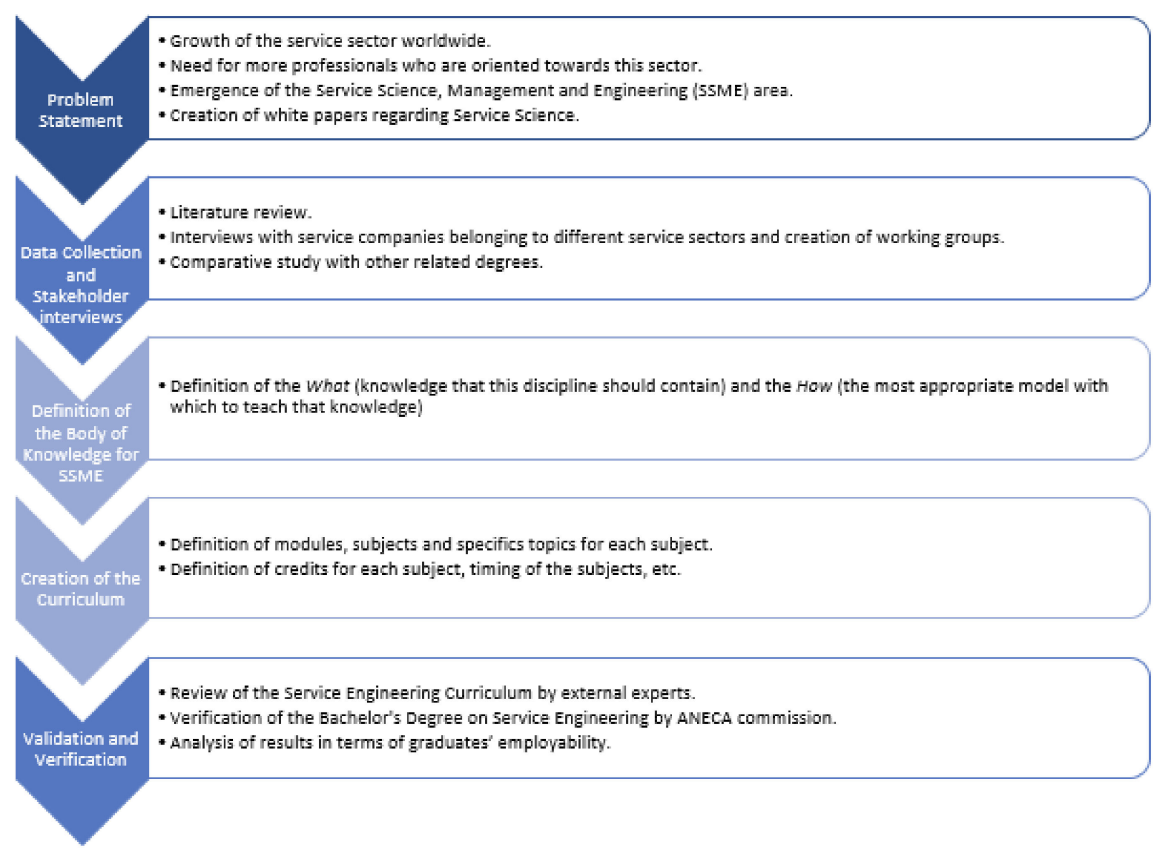

Figure 7. Work method for the development of the RJCU Service Engineering Curriculum.

The validation and verification of the Service Engineering Curriculum were first carried out by reviewing experts belonging to different service organizations (such as the ERISS, the SRII, the ISSIP, and the IBM Service Research Center in Almaden), and were later formally verified by the Spanish governmental agency in charge of the assessment and accreditation of higher-education programs (ANECA - Agencia Nacional de Administración de la Calidad y Acreditación). A study of the employability of the first students to graduate from the proposed degree is presented in the following section of this work.

The degrees in SSME that are currently available are shown in Table 5. One important difference that will be observed in the degrees in SSME that are currently being taught is the influence of those areas most closely related to SSME, such as engineering, information technology, and business management. The degree profiles most closely related to information technology, which is taught at schools of computer science, are clearly different to those more closely related to business management, which are principally taught at business schools. There are also various degrees that have a strong component of the classical types of engineering, such as industrial engineering, telematic engineering, or that related to telecommunications. Despite the fact that all the degrees analyzed herein are focused on the concept of service, some are clearly more oriented towards the IT service or digital services, while others are more focused on service management and the management of services as a business activity. 
Table 5. Comparison of Degrees in SSME.

\begin{tabular}{|c|c|c|c|c|}
\hline Id & Title & University-School & $\begin{array}{l}\text { Profile } \\
\end{array}$ & Representative Topics \\
\hline 1 & $\begin{array}{c}\text { BSc in Business } \\
\text { Administration and Service } \\
\text { Management }\end{array}$ & $\begin{array}{l}\text { Copenhagen Business } \\
\text { School }\end{array}$ & $\begin{array}{l}\text { Business }+ \text { Service } \\
\text { Management }\end{array}$ & $\begin{array}{l}\text { Managerial Economics, Financial Accounting, Macroeconomics, Service Management Foundations, Public } \\
\text { Regulations }\end{array}$ \\
\hline 2 & $\begin{array}{l}\text { Service EngineeringBachelor } \\
\text { of Engineering }\end{array}$ & $\begin{array}{l}\text { Frankfurt University of } \\
\text { Applied Science }\end{array}$ & $\begin{array}{l}\text { Mechanical/Electrical } \\
\text { Engineering + Service } \\
\text { Management }\end{array}$ & $\begin{array}{l}\text { Industrial Engineering, Electrical Engineering, IT, Electronic, DB Management, Applied Programming, Service } \\
\text { Management, Accounting, Marketing, etc. }\end{array}$ \\
\hline 3 & Service Management & $\begin{array}{l}\text { Furtwangen University } \\
\text { (HFU)-Business } \\
\text { Administration and } \\
\text { Engineering }\end{array}$ & $\begin{array}{l}\text { Business }+ \text { Service } \\
\text { Management }\end{array}$ & $\begin{array}{l}\text { Applied Mathematics, Business Accounting, Electrical Engineering with laboratory, Marketing and Services, } \\
\text { Physical Engineering with laboratory, General Business Administration, Design and Manufacturing, Technical } \\
\text { Mechanics, etc. }\end{array}$ \\
\hline 4 & $\begin{array}{l}\text { IT Service Science major - } \\
\text { Bachelor of Computer and } \\
\text { Information Sciences }\end{array}$ & $\begin{array}{l}\text { Auckland University of } \\
\text { Technology - Computer and } \\
\text { Mathematical Sciences }\end{array}$ & ICT + Service Management & $\begin{array}{l}\text { Applied Communication, Programming, Computing Technology in Society, Foundations of IT Infrastructure, } \\
\text { Computer Network Principles, Enterprise Systems, IT Project Management, IT Service Provision, Data and Process } \\
\text { Modelling, IT Strategy and Control, IT Service Management, etc. }\end{array}$ \\
\hline 5 & $\begin{array}{l}\text { Bachelor of Science in } \\
\text { Industrial Management } \\
\text { Engineering minor in } \\
\text { Service Management (BS } \\
\text { IME-SM) }\end{array}$ & $\begin{array}{l}\text { De La Salle University - } \\
\text { Gokongwei College of } \\
\text { Engineering }\end{array}$ & $\begin{array}{l}\text { Industrial Engineering + } \\
\text { Service Management }\end{array}$ & $\begin{array}{l}\text { Economic Analysis, Marketing, Probability and Statistics, Financial Accounting, Industrial Engineering } \\
\text { Mathematics, Industrial Cost Accounting, Production/Operations Management, Operations Research, Industrial } \\
\text { Engineering Economy, Human Behavior in Organization, Fundamentals of Financial Management, Product Design, } \\
\text { Management of Service Operations, Management of Food Service Systems, Retail Management, Introduction to } \\
\text { Banking Industry, Business Process Outsourcing, Introduction to Healthcare Management, etc. }\end{array}$ \\
\hline 6 & $\begin{array}{l}\text { Bachelor's Degree in } \\
\text { Information Technology } \\
\text { and Services }\end{array}$ & $\begin{array}{l}\text { Universitat Autònoma de } \\
\text { Barcelona-Escuela } \\
\text { Universitaria de Informática } \\
\text { "Tomàs Cerdà" }\end{array}$ & ICT + Services & $\begin{array}{l}\text { Mathematics for Computing and Services, Principles of Programming, Service Sociology, Service Company } \\
\text { Business Model, Person-Computer Integration, Web and Multi-Media Application Design, Databases, } \\
\text { Service-Orientated Architecture, Project Management, Service Design and Motorization, Service Analysis and } \\
\text { Modelling, Service-Oriented Business Consultation Methodology, Knowledge Management and Innovation, } \\
\text { Auditing and Service Quality, etc. }\end{array}$ \\
\hline 7 & $\begin{array}{l}\text { Bachelor's Degree in } \\
\text { Telecommunication } \\
\text { Technologies and Services } \\
\text { Engineering }\end{array}$ & $\begin{array}{l}\text { Polytechnic University of } \\
\text { Madrid-Technical School of } \\
\text { Telecommunication } \\
\text { Engineers }\end{array}$ & Telco + Digital Services & \multirow{2}{*}{$\begin{array}{l}\text { Physics, Programming, and Management, Electronic Devices, Circuit Theory, Foundations of Networking, } \\
\text { Computer fundamentals, Fundamentals of Business Organization, Electronic Circuits, Signals and Systems, } \\
\text { Communication Theory, Networking Architectures Design of telematic services, Telematic Applications, Integration } \\
\text { of Digital Systems, Multimedia Communications, etc. }\end{array}$} \\
\hline 8 & $\begin{array}{l}\text { Bachelor's Degree in } \\
\text { Telecommunication } \\
\text { Technologies and Services } \\
\text { Engineering } \\
\end{array}$ & $\begin{array}{l}\text { Polytechnic University of } \\
\text { Valencia-School of } \\
\text { Telecommunications } \\
\text { Engineering }\end{array}$ & Telco + Digital Services & \\
\hline 9 & $\begin{array}{l}\text { Bachelor's Degree in } \\
\text { Service Engineering }\end{array}$ & $\begin{array}{l}\text { Rey Juan Carlos } \\
\text { University-Faculty of Social } \\
\text { Science }\end{array}$ & $\begin{array}{l}\text { ICT }+ \text { Human }+ \text { Service } \\
\text { Management }\end{array}$ & See Table 4 \\
\hline 10 & $\begin{array}{l}\text { Baccalauréat Universitaire } \\
\text { en Systèmes d'Information } \\
\text { et Science des Services }\end{array}$ & $\begin{array}{c}\text { University of } \\
\text { Geneva-Institute of } \\
\text { Information Service Science }\end{array}$ & ICT + Digital Service & $\begin{array}{l}\text { Data and information, Modelization, Design and analysis, Programming and Digital services, Networks and } \\
\text { Security, Ethics and Regulations, Innovation and Design, etc. }\end{array}$ \\
\hline 11 & $\begin{array}{l}\text { Bachelor of Science in } \\
\text { Industrial and Service } \\
\text { Engineering and } \\
\text { Management }\end{array}$ & Nile University & $\begin{array}{l}\text { Engineering + Service } \\
\text { Management }\end{array}$ & $\begin{array}{l}\text { Production and Manufacturing, Engineering Management, Service Engineering and Management, Human Factors } \\
\text { and ergonomics, Logistics and Supply Chain Management, Quality Engineering and Management, etc. }\end{array}$ \\
\hline 12 & $\begin{array}{l}\text { Information Technology } \\
\text { Services }\end{array}$ & Mississippi State University & ICT + Business & $\begin{array}{l}\text { Computer Applications, Database Management, Spreadsheet Design \& Analysis, Computer Repair and } \\
\text { Maintenance, Design Technology, Information Technology Project Management, Introduction to Data Networks, } \\
\text { Graphics and Web Design, Delivery and Evaluation of Technology, Financial and Managerial Accounting, Legal } \\
\text { Environment of Business, Principles of Macroeconomics and Microeconomics, Principles of Management, Human } \\
\text { Resource Management, Web Development, Management Information Systems, etc. }\end{array}$ \\
\hline
\end{tabular}


The degrees that are less influenced by information technology and classical engineering would appear to be closer to the idea of an SSME degree, since new knowledge arises from the synergy of various disciplines (technologies, business, human aspects) and are more focused on service management. A classification of the current degrees according to their relationship with the main SSME disciplines, along with the aforementioned tendencies as regards integrating the concept of services, is shown in Figure 8.

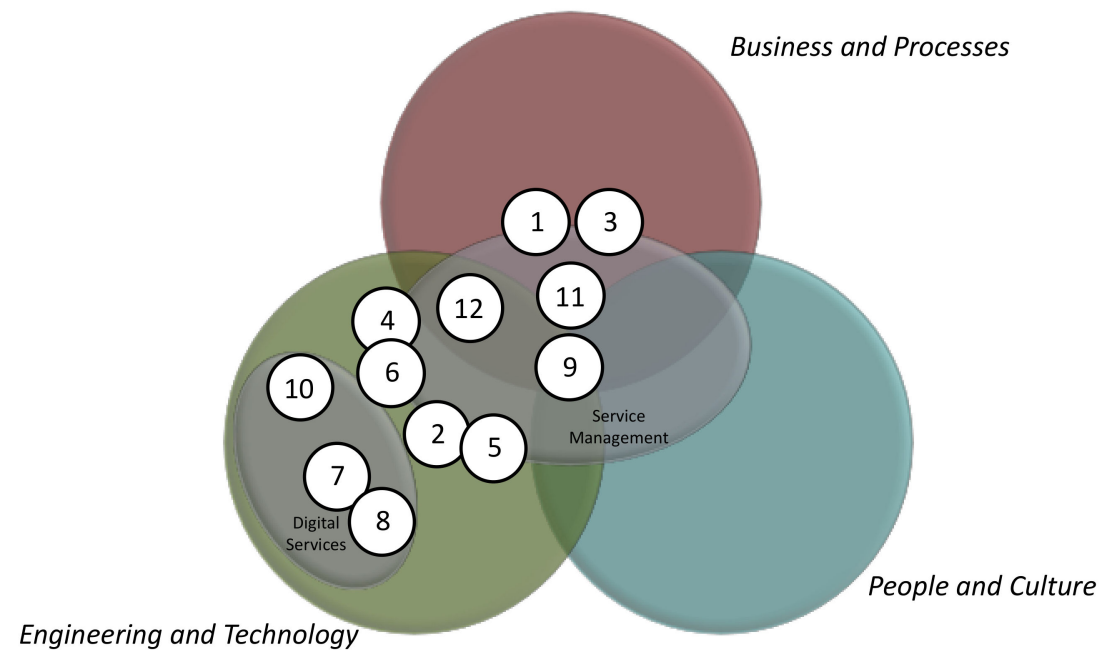

Figure 8. Classification of SSME degrees.

Of the degrees analyzed, four have contents that are more closely related to the area of information and communications technology (ICT): (4), (6), (10), and (12). As will be noted in Table 5, these degrees provide a considerable amount of training in traditional ICT or IS subjects, such as programming, networks, databases, IT project management, etc. In the case of degree (10), the knowledge regarding services is focused on providing students with the skills required to develop and create digital services.

There are, moreover, other degrees that are more closely related to classical engineering, and it is here that we find the interdisciplinary degrees (2) and (5), which integrate knowledge concerning mechanical and industrial engineering with that of business management and services in an attempt to contribute towards providing a more complete professional profile for manufacturing companies. Degrees (7) and (8) are fundamentally degrees in telecommunications engineering that integrate skills for the development of digital and telematic services.

Some of the degrees that are most influenced by the area of business management and which are available at business schools are (1) and (3), which combine classical business knowledge with concepts of service management, with the idea of creating a profile that is more oriented towards the service business and markets. Degree (11) provides training in service engineering and management and is focused on industry, but has aspects of engineering, human factors, and management integrated into it.

As mentioned throughout this work, in the specific case of the degree taught at RJCU (9), there has been particular interest in creating a study plan that will make it possible to educate graduates to attain a transdisciplinary SSME profile. This aspect is reflected in the balanced distribution of subjects and contents in the areas of the degree. Moreover, the concept of sustainable business and its implications for management have also been incorporated.

\section{Graduates: Analysis of the Employability and Need for the Profile}

In order to nurture human resources who can adapt to different changes across the economic and social landscape, the field of education should not only focus on imparting knowledge related to specific majors but also enable students to understand and adapt to the demands of a rapidly changing society [22]. 
"Educators should also help students develop competencies that will enable them to comprehensively analyze and resolve the diverse problems of such a society" [22] (p. 1). Putting the Service Engineering Curriculum into practice has, therefore, been a great challenge. In keeping with the requirement to train students to reflect on, analyze, and resolve problems in the area of services, the analysis of the employability associated with graduates, along with the suitability of those graduates for a particular job, proved to be key indicators.

The service-centered and transdisciplinary training profile proposed and developed by RJCU would appear to be well adapted to the labor market in Spain. In order to verify the level of employability of those who have completed this degree, we carried out a survey of the graduates, to which 37 out of 73 responded.

Of all those who responded, $89 \%$ are currently working (see Figure 9). This is a relatively high percentage of employment if we compare it with percentages concerning the employment of those who have graduated from related degrees, such as business administration $(77.4 \%)$, engineering and its related professions (80.1\%), or computer science (84.6\%) [23]. It is important to note that graduates in service engineering have a relatively new and different profile, and beyond improving the percentage of employment in this area, the important point is their adjustment to the specifics needs of the service sector in terms of knowledge and skills.

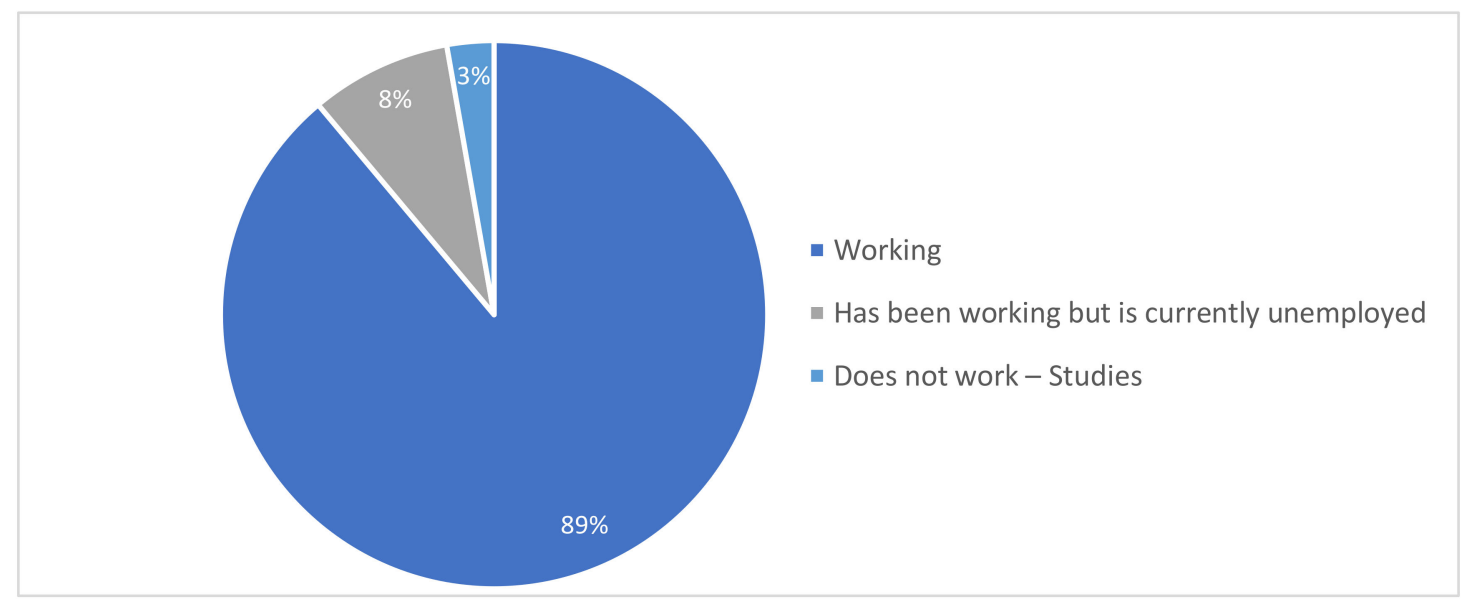

Figure 9. Graduates' employment status.

The posts occupied by the service engineering graduates are principally related to consultation (48\%) and management (31\%). The remaining graduates' jobs are technical (development, maintenance, etc.), or concern marketing, UX design, and sales, among others. It is also important to stress that $78 \%$ of the graduates have permanent contracts with their companies and that the majority of them $(81 \%)$ have been working for more than six months.

In order to assess the way in which the graduates evaluate the education that they received, we asked them to indicate, on a scale of 1 to 10 , the suitability of the competences and skills that they acquired on the degree for the job that they are currently doing. Fifty percent of them considered that they were highly appropriate (scores of between 8 and 10), 39\% considered that they were of a medium level (scores of between 4 and 7), while the remaining 11\% considered that they were of a low level (scores of between 1 and 3). Figure 10 shows the mean scores obtained, taking into account the duties that they actually perform during the course of their work. It will be noted that the highest scores were obtained from those working in management and UX design, while the lowest scores were obtained from those working in marketing. This coincides with the expectations of the training since it was not a degree in marketing but rather a type of training that would allow the graduates to adapt to this type of work. 


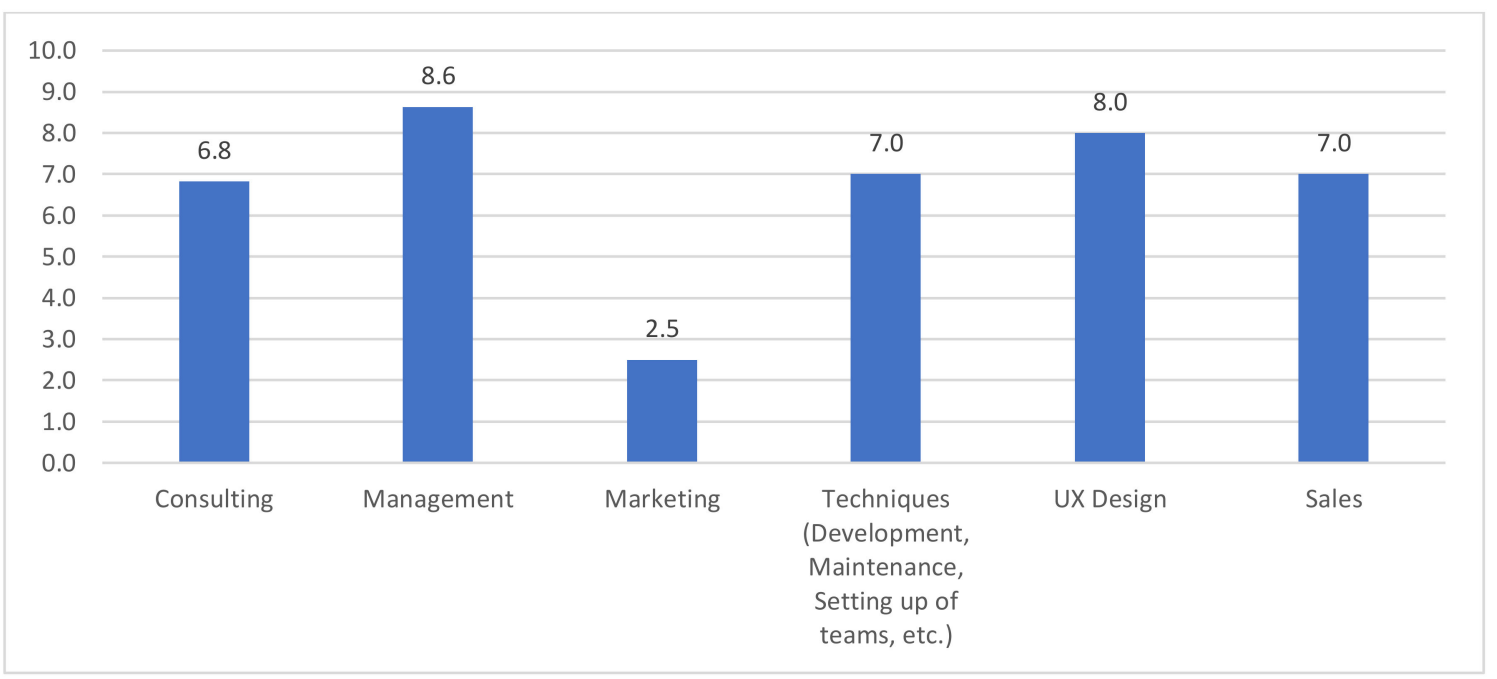

Figure 10. Average scores (out of 10) as regards the suitability of the competences and skills acquired in relation to the duties performed during the course of the graduates' work.

With regard to seeking employment, $28 \%$ of the graduates stated that they did not have to seek employment because they were taken on by the company at which their work experience took place, while $5 \%$ were offered employment directly. Of those who sought employment ( $61 \%$ of the graduates), $64 \%$ stated that they found work after one month or less, while the remaining $36 \%$ did so in 2 to 3 months.

From a more qualitative point of view, it is important to highlight that one of the main advantages of the degree is the wide range of jobs open to the graduates (sales, design, management, consulting, etc.). Another benefit is undoubtedly the employment situation that is open to recent graduates; note that a high percentage of them begin in consulting or management posts at a level that is not usually accessible for recent graduates owing to their lack of experience. In addition to requiring technical and specific knowledge, these positions also require personal and social skills that traditional graduates do not tend to have, and which are generally acquired over time.

The need for graduates with this type of profile has been shown by many service organizations, which currently operate more endogenously and form this profile in an ad-hoc manner using their internal training plans. This subsection shows some of the statements obtained after carrying out interviews with service sector professionals and which confirm this requirement (contents of the Service Engineering MOOC available online: https://miriadax.net/web/ingenieria-de-servicios).

Mar Ruiz, service manager of the EULEN Group and Oscar García, head of the Facility Services Project at the same company consider that "the education traditionally provided by universities is no more than the gateway into our company; our employees then have to be trained by means of internal training plans, which prepare them to become service managers."

The transdisciplinary profile is also a fundamental requirement for many organizations that discover that this is lacking in their professionals. Vicente del Poyo, vice-president of MELIA Hotels International commented that the vast majority of the managers in his organization have an education based on economics and financing, but do not have leadership skills or technological knowledge. Lourdes Ripoll, associate vice-manager to the CEO of MELIA Hotels International, stated the need for engineers in the tourism sector: "The traditional training in tourism is perfectly valid for some positions in the sector. But we also require professionals with the capacity to plan, design and manage both material and human resources."

Elisa Martin Garijo, director of technology and innovation at IBM Spain, stated that the training required by a service professional is also carried out internally at IBM, "but it is very long training based on day-to-day experience". Sra. Garijo considers that it vital to have a basis in service training: "It is very important to begin to train people who understand these concepts from the outset and who 
think about these concepts in a systematic manner from the very beginning. This type of professionals should have highly multidisciplinary profiles, and not just knowledge of mathematics and humanities, but also of laws, social relations, formalizations, and communication. It is a very varied profile, and the responsibility for the creation of this type of profile lies with universities."

Ricardo Gabarro, who is the EULEN Group's R+D+I manager, considers that "the type of training most required in the future will be that of service engineers, and they will probably be the most polyvalent, as were industrial engineers in their time, since they were valid for any type of engineering. A service engineer will be valid for every aspect of the world of services, i.e., commercial operative and technical activities, and everything will be services in the future."

\section{Conclusions}

This paper presents a project involving the creation of a service engineering degree at a public university in Spain: Rey Juan Carlos University. As has been explained, this is the first degree in SSME to have a holistic and transdisciplinary focus, as would be expected for this emerging discipline. The degree was designed by SSME experts from the university and the service sector.

One of the principal challenges was precisely the difficulty involved in creating a transdisciplinary degree, in addition to attempting to explain the difference between the proposed degree and other already functioning degrees of an inter- or multi-disciplinary nature. As is shown in this paper, education in SSME implies providing a new type of professional for the service sector. This professional is educated by combining the SSME knowledge areas with a T-shaped-type profile.

This work makes three main contributions:

For the company: The training of professionals specific to a sector that is clearly growing at a worldwide level. This will make it possible to improve the productivity of service sector companies, owing to the availability of service experts with a holistic vision of those services, from their conception to post-sales. It is clearly committed to the management of sustainable business.

For the student: They will receive training in an emerging discipline that nevertheless has a great business fabric. This signifies that future graduates will have a high level of employability, along with excellent work prospects that can only improve, since they are expected to be the future managers and executives of service companies from different spheres.

For society: This is directly derived from the two previous reasons. Public universities' responsibility as regards giving something back to society should not be forgotten, and this degree could contribute to improving the most important sector for the economies of the majority of developed countries at what is a difficult moment for those economies. This contribution could also be extended to developing countries, since the growth of the services sector is the immediate consequence as their economy progresses, and having professionals already trained in the sector is an appropriate measure by which to further promote their development.

As has been shown, the degree leads to a high rate of employability and its graduates are incorporated into companies at higher levels than the holders of other degrees such as computer engineering. The contracting companies are highly satisfied with the graduates' training and are demanding more with this type of profile.

New companies from other spheres, such as transport and organizations like IFMA (International Facility Management Association, https:/www.ifma.org/), are currently being incorporated into this project. This new group has led to the need to review the contents of the degree in order to ensure that there are no gaps in some of the service sector spheres. We are also beginning to establish collaborations for the teaching of classes, such that the students will have both an academic and a business perspective. Moreover, we continue following up the graduates' progress as regards their employability and their results at companies, etc., and all of this will undoubtedly lead us to once again revise the degree program.

One of our next steps will be to set up master's degree and doctorate programs, which will make it possible to provide the students with continuity, and the degree will additionally benefit 
from the synergy of research. In this respect, the university already has a transdisciplinary SSME research group, which was involved in designing the degree presented herein. This group is composed of SSME experts from the areas of business, ICT, communication, and humanities. The creation of transdisciplinary research groups is, therefore, a challenge that may additionally provide interesting results when tackling social and economic problems from a broader perspective.

Author Contributions: Conceptualization, E.M., V.D.C., M.-L.M.-P., and J.M.V.; formal analysis, M.-L.M.-P. and J.M.V.; investigation, E.M., V.D.C., M.-L.M.-P., and J.M.V.; methodology, E.M. and V.D.C.; project administration, E.M.; supervision, V.D.C.; visualization, J.M.V.; writing-original draft, E.M.; writing-review and editing, V.D.C. and M.-L.M.-P. All authors have read and agreed to the published version of the manuscript.

Funding: This work has been partially funded by the Regional Government of Madrid, through the FORTE-CM project (S2018/TCS-4314) and the Spanish MINECO, through the MADRID project (TIN2017-88557-R).

Acknowledgments: We would also like to thank all the participants in this project: the experts from IBM Spain (Victor Camargo, Soledad Linniers, Elisa Guijarro, Jesús Freire) and EULEN (Ricardo Gabarro), the external advisors and external reviewers at ISSIP (Jim Spohrer, IBM Innovation Champion and Director of the IBM University Programs World Wide), SRII (Pere Botella, Full professor in the Services \& Information Systems Engineering Department at the Universitat Politècnica de Catalunya), ERISS (Mike Papazogou, executive director at the University of Tilburg) and IBM-Almaden (Jorge Sanz, currently Chief Innovation Officer, Retail Banking Industry, IBM), and reviewers at the ANECA Commission. Their collaboration has been a key aspect as regards achieving good results. We would particularly like to mention Pedro Lázaro (IBM Spain), one of the principal driving bodies behind SSME in Spain, and especially behind this project, and who we unfortunately lost along the way.

Conflicts of Interest: The authors declare no conflict of interest.

\section{Appendix A}

Table A1. Current undergraduate and graduate SSME programs.

\begin{tabular}{|c|c|c|}
\hline Denomination & University-School & Country \\
\hline $\begin{array}{c}\text { BSc in Business Administration and Service } \\
\text { Management }\end{array}$ & Copenhagen Business School & Denmark \\
\hline $\begin{array}{c}\text { Service Engineering Bachelor's Degree in } \\
\text { Engineering }\end{array}$ & Frankfurt University of Applied Science & Germany \\
\hline Service Management & $\begin{array}{l}\text { Furtwangen University (HFU)_Business } \\
\text { Administration and Engineering }\end{array}$ & Germany \\
\hline $\begin{array}{l}\text { IT Service Science major-Bachelor of Computer } \\
\text { and Information Sciences }\end{array}$ & $\begin{array}{c}\text { Auckland University of Technology-Computer and } \\
\text { Mathematical Sciences }\end{array}$ & New Zealand \\
\hline $\begin{array}{l}\text { Bachelor of Science in Industrial Management } \\
\text { Engineering minor in Service Management }\end{array}$ & $\begin{array}{c}\text { De La Salle University-Gokongwei College of } \\
\text { Engineering }\end{array}$ & Philippines \\
\hline $\begin{array}{c}\text { Bachelor's Degree in Information Technology and } \\
\text { Services }\end{array}$ & $\begin{array}{l}\text { Universitat Autònoma de Barcelona-Escuela } \\
\text { Universitaria de Informática “Tomàs Cerdà" }\end{array}$ & Spain \\
\hline $\begin{array}{l}\text { Bachelor's Degree in Telecommunication } \\
\text { Technologies and Services Engineering }\end{array}$ & $\begin{array}{l}\text { Polytechnical University of Madrid-Technical } \\
\text { School of Telecommunication Engineers }\end{array}$ & Spain \\
\hline $\begin{array}{l}\text { Bachelor's Degree in Telecommunication } \\
\text { Technologies and Services Engineering }\end{array}$ & $\begin{array}{l}\text { Polytechnical University of Valencia-School of } \\
\text { Telecommunications Engineering }\end{array}$ & Spain \\
\hline Bachelor's Degree in Service Engineering & Rey Juan Carlos University_-Faculty of Social Science & Spain \\
\hline $\begin{array}{l}\text { Baccalauréat Universitaire en Systèmes } \\
\text { d'Information et Science des Services }\end{array}$ & $\begin{array}{l}\text { University of Geneva-Institute of Information } \\
\text { Service Science }\end{array}$ & Switzerland \\
\hline $\begin{array}{l}\text { Bachelor of Science in Industrial and Service } \\
\text { Engineering and Management }\end{array}$ & Nile University & Nigeria \\
\hline Information Technology Services & Mississippi State University & USA \\
\hline Denomination & University-School & Country \\
\hline $\begin{array}{l}\text { Business Administration and Engineering-Sales } \\
\text { and Service Engineering }\end{array}$ & $\begin{array}{l}\text { Furtwangen University (HFU)_Business } \\
\text { Administration and Engineering School }\end{array}$ & Germany \\
\hline $\begin{array}{c}\text { Master's Degree in Service Engineering and } \\
\text { Management }\end{array}$ & $\begin{array}{c}\text { Universidade do Porto-Department of Industrial } \\
\text { Engineering and Management }\end{array}$ & Portugal \\
\hline
\end{tabular}


Table A1. Cont.

\begin{tabular}{|c|c|c|}
\hline Denomination & University-School & Country \\
\hline $\begin{array}{c}\text { Master's Degree in Service Science, Management, } \\
\text { and Engineering }\end{array}$ & Masaryk University—Faculty of Informatics & Czech Republic \\
\hline $\begin{array}{c}\text { Master's Program in Information and Service } \\
\text { Management }\end{array}$ & Aalto University—School of Business & Finland \\
\hline Service Management and Design (SMD) & $\begin{array}{l}\text { University of Warwick-WMG-International } \\
\text { Manufacturing Centre }\end{array}$ & United Kingdom \\
\hline Master's Program in Service Management & $\begin{array}{l}\text { Karlstad University_-Faculty of Arts and Social } \\
\text { Sciences }\end{array}$ & Sweden \\
\hline MSc in Social Science in Service Management & Copenhagen Business School & Denmark \\
\hline Master's Degree in Service Design & Politécnico de Milano-PoliDesing & Italy \\
\hline $\begin{array}{c}\text { Master's Degree in Business, Product and Service } \\
\text { Management }\end{array}$ & $\begin{array}{l}\text { Polytechnic University of Valencia-Faculty of } \\
\text { Business Administration and Management }\end{array}$ & Spain \\
\hline $\begin{array}{l}\text { Master's Degree in Strategic Design of Products } \\
\text { and Services }\end{array}$ & Mondragon University & Spain \\
\hline M.F.A. in Service Design & Savannah College of Art and Design & USA \\
\hline Master's Program in Service Management & $\begin{array}{l}\text { Lund University-Department of Service } \\
\text { Management and Service Studies }\end{array}$ & Sweden \\
\hline Master's Program in IT Service Management & $\begin{array}{l}\text { University of Northampton-Northampton Business } \\
\text { School }\end{array}$ & United Kingdom \\
\hline $\begin{array}{c}\text { International Master's Degree in Service } \\
\text { Engineering }\end{array}$ & $\begin{array}{l}\text { University of Tilburg-European Research Institute } \\
\text { in Service Science (ERISS), University of Stuttgart. }\end{array}$ & $\begin{array}{l}\text { The Netherlands, } \\
\text { Germany, Greece }\end{array}$ \\
\hline $\begin{array}{c}\text { Master's Degree in Service Design and } \\
\text { Engineering }\end{array}$ & $\begin{array}{l}\text { EIT ICT Labs Master School. University of Trento, } \\
\text { TU Eindhoven, Aalto University and ELTE Budapest. }\end{array}$ & $\begin{array}{c}\text { Italy, The } \\
\text { Netherlands, } \\
\text { Finland, Hungary. }\end{array}$ \\
\hline $\begin{array}{l}\text { Services Management concentration in the MBA } \\
\text { program }\end{array}$ & $\begin{array}{c}\text { North Caroline State University-College of } \\
\text { Management }\end{array}$ & USA \\
\hline Service Engineering and Management & $\begin{array}{c}\text { University Politehnica of Bucharest-Faculty of } \\
\text { Automatic Control and Computers }\end{array}$ & Romania \\
\hline Master of Science Degree in Foreign Service & $\begin{array}{c}\text { Georgetown University—Faculty of the School of } \\
\text { Foreign Service }\end{array}$ & USA \\
\hline $\begin{array}{c}\text { Master of Science Degree in Public Service } \\
\text { Management }\end{array}$ & $\begin{array}{c}\text { DePaul University-College of Liberal Arts and } \\
\text { Social Sciences }\end{array}$ & USA \\
\hline MSc in Service Innovation and Management & $\begin{array}{c}\text { University of Jyväskylä-Faculty of Information } \\
\text { Technology }\end{array}$ & Finland \\
\hline $\begin{array}{c}\text { Master's Degree in Social Sciences and Social } \\
\text { Service Management }\end{array}$ & $\begin{array}{c}\text { The University of Hong Kong-Faculty of Social } \\
\text { Sciences }\end{array}$ & China \\
\hline Master's Program in Service Management & $\begin{array}{l}\text { University of Eastern Finland-Faculty of Social } \\
\text { sciences }\end{array}$ & Finland \\
\hline Master's Degree in Design for Services & University of Dundee-Faculty of design & United Kingdom \\
\hline $\begin{array}{c}\text { Master's Degree in Global Operations and Service } \\
\text { Management }\end{array}$ & Aston University-Aston Business School & United Kingdom \\
\hline Master's Degree in Service Management & $\begin{array}{l}\text { Universidade Católica Portuguesa-Faculty of Social } \\
\text { sciences }\end{array}$ & Portugal \\
\hline Master's Degree in Engineering Management & University of Nicosia-Faculty of Social sciences & Cyprus \\
\hline
\end{tabular}

\section{References}

1. Martín-Peña, M.L.; Díaz-Garrido, E. Fundamentos de Dirección de Operaciones en Empresas de Servicios; Esic Editorial: Madrid, Spain, 2013.

2. Spohrer, J.; Fodell, D.; Murphy, W. Ten Reasons: Service Science Matters to Universities. Educause Rev. 2012, 47, 52.

3. IfM, IBM. Succeeding Through Service Innovation: A Service Perspective for Education, Research, Business and Government; University of Cambridge Institute for Manufacturing: Cambridge, UK, 2008.

4. Glushko, R.J. Designing a Service Science discipline with discipline. IBM Syst. J. 2008, 47, 15-27. [CrossRef]

5. Marcos-Martínez, E.; Martín-Peña, M.L. Formación de profesionales para la empresa del siglo XXI. Rev. Vasca Econ.-Ekomomiaz 2016, 89, 174-193. 
6. Hefley, B.; Murphy, W. Service Science, Management and Engineering: Education for the 21st Century; Springer: Berlin/Heidelberg, Germany, 2008.

7. Spohrer, J.; Maglio, P. The Emergence of Service Science: Toward Systematic Service Innovations to Accelerate Co-Creation of Value. Product. Operat. Manag. 2008, 17, 238-246. [CrossRef]

8. Lázaro, P.; Galán, L.; Suárez, B.; Domínguez, A. La Ciencia de los Servicios: Un desafío para el sistema universitario español. In Programa de Estudios y Análisis del Ministerio de Educación; Proyecto EA2008-0307; Ministerio de Educación: Madrid, Spain, 2008.

9. IBM Research. Services Sciences: A New Academic Discipline? Report on the Architecture of On Demand Business Summit; Yorktown Heights, New York. 2004. Available online: http://www.almaden.ibm.com/asr/ SSME/facsummit.pdf (accessed on 17 September 2016).

10. Stoshikja, M.; Kryvinskaa, N.; Straussa, C. Service Systems and Service Innovation: Two pillars of Service Science. Proc. Comput. Sci. 2016, 83, 212-220. [CrossRef]

11. Spohrer, J.; Kwan, S.K. Service science, management, engineering, and design (SSMED): An emerging discipline-outline and references. Int. J. Inf. Syst. Serv. Sect. 2009, 1, 1-31. [CrossRef]

12. Bishop, K. Succeeding through service innovation: A service perspective for education, research, business and government. In White Paper Based on Cambridge Service Science, Management and Engineering Symposium; University of Cambridge \& IBM: Cambridge, UK, 2004.

13. Maglio, P.; Spohrer, J. Fundamentals of service science. J. Acad. Market. Sci. 2008, 36, 18-20. [CrossRef]

14. Kieliszewski, C. Educating the New Service Professional: What are the Essentials of a Service Curriculum? Workshop on Service Science, Managernent and Engineering (SSME) Education: Looking Ahead Co-Located with ICSOC 2008 Workshops; University of Technology: Sidney, Australia, 2008.

15. Toomey, A.H.; Markusson, N.; Adams, E.; Brockett, B. Inter-Inter- and Trans-Disciplinary Research: A Critical Perspective; Global Sustainable Development Report 2015. Available online: https://sustainabledevelopment.un.org/content/documents/612558-Inter-\%20and\%20Trans-disciplinary\% 20Research\%20-\%20A\%20Critical\%20Perspective.pdf (accessed on 1 October 2020).

16. Kajzer Mitchell, I.; Walinga, J. The creative imperative: The role of creativity, creative problem solving and insight as key drivers for sustainability. J. Clean. Prod. 2017, 140, 1872-1884. [CrossRef]

17. Tasdemir, C.; Gazo, R. Integrating sustainability into higher education curriculum through a transdisciplinary perspective. J. Clean. Prod. 2020, 265. [CrossRef]

18. IT Service Science Major: Bachelor of Computer and Information Sciences. School of Computing and Mathematical Sciences. Auckland University of Technology (New Zealand). Available online: https://www.aut.ac.nz/study/study-options/engineering-computer-and-mathematicalsciences/courses/bachelor-of-computer-and-information-sciences (accessed on 1 October 2020).

19. Baccalauré at Universitaire en Systèmes d'Information et Science des Services. Facultad de Ciencias Económicas y Sociales. Universidad de Ginebra (Suiza). Available online: https://cui.unige.ch/fr/formations/ bachelors/bachelor-en-systemes-dinformation-et-science-des-services/ (accessed on 1 October 2020).

20. Bachelor of Science in Human Services with a concentration in Management. College of Social Sciences. University of Phoenix (USA). Available online: http://www.phoenix.edu/programs/degree-programs/humanservices/bachelors/bshs-m.html\#tab=overview (accessed on 1 October 2020).

21. Ullah, F.; Sepasgozar, S.; Tahmasebinia, F.; Sepasgozar, S.M.E.; Daviss, S. Examining the impact of students' attendance, sketching, visualization, and tutors experience on students' performance: A case of building structures course in construction management. Constr. Econ. Build. 2020, 20, 78-102.

22. Lim, J.; Yoon, J.; Kim, M. Analysis of the Educational Needs Related to, and Perceptions of the Importance of, Essential Job Competencies among Science and Engineering Graduates. Educ. Sci. 2020, 10, 85. [CrossRef]

23. Labour Insertion Report of University Graduates. Spanish Ministry of Science, Innovation, and Universities. Available online: https://www.ciencia.gob.es/stfls/MICINN/Prensa/FICHEROS/2018/190704-Informe_ Laboral.pdf (accessed on 1 October 2020).

(C) 2020 by the authors. Licensee MDPI, Basel, Switzerland. This article is an open access article distributed under the terms and conditions of the Creative Commons Attribution (CC BY) license (http://creativecommons.org/licenses/by/4.0/). 